\title{
PENERAPAN TEKNOLOGI PRODUKSI SIMPLISIA EMPON-EMPON, KELOMPOK TANI KECAMATAN TRAWAS, KABUPATEN MOJOKERTO, JAWA TIMUR
}

\author{
Oleh: \\ Mirwa Adiprahara Anggarani ${ }^{1}$, Erlix Rakhmad Purnama ${ }^{2}$, Raya Sulistyowati ${ }^{3}$ \\ ${ }^{1}$ Jurusan Kimia, Fakultas Matematika dan Ilmu Pengetahuan Alam, Universitas Negeri \\ Surabaya \\ 2Jurusan Biologi, Fakultas Matematika dan Ilmu Pengetahuan Alam, Universitas Negeri \\ Surabaya \\ ${ }^{3}$ Jurusan Pendidikan Tata Niaga, Fakultas Ekonomi, Universitas Negeri Surabaya \\ 1mirwaanggarani@unesa.ac.id
}

\begin{abstract}
Abstrak
Pengabdian masyarakat ini bertujuan untuk mengatasi beberapa permasalahan utama yang dialami oleh petani empon-empon, yakni keterbatasan pengetahuan mengenai teknik produksi simplisia empon-empon dan fasilitas produksi simplisia empon-empon yang kurang memadai. Permasalahan tersebut yang dialami oleh UMKM mitra "Gunung Jambe", Kecamatan trawas, Kabupaten Mojokerto, Jawa Timur. Untuk mencapai tujuan program PKM ini perlu dilakukan introduksi iptek mengenai: (1) optimalisasi pembuatan simplisia empon-empon berkualitas ekspor (SNI: 01-3393-1994); (2) analisa kandungan gizi simplisia empon-empon; (3) analisa masa simpan produk simplisia empon-empon. Pelaksanaan kegiatan PKM dilakukan antara bulan Mei hingga September 2019. Pada introduksi iptek optimalisasi pembuatan simplisia empon-empon berkualitas ekspor, amak dalam kegiatan ini peserta PKM memliki keampuan memproduksi simplisia empon-empon sesuai standart ekspor, yakni SNI:01-33931994. Berdasarkan hasil analisa kandungan gizi produk simplisia empon-empon, diketahui bahwa simplisia empon-empon mengandung kadar air sebesar 1,54\%; kadar abu sebesar 9,45\%; karbohidrat sebesar 86,70\%; lemak sebesar 0,91\%; dan protein sebesar 1,41\%. Dari hasil pelaksanaan PKM di bulan Juni 2019, nampak antusiasme yang sangat tinggi dari peserta PKM. Selain itu terdapat beberapa masukan dari peserta pelatihan terkait kegiatan selanjutnya yang disampaikan melalui angket peserta pelatihan.
\end{abstract}

Kata Kunci: simplisia empon-empon, introduksi iptek, PKM

\begin{abstract}
The community service aims to solve several main problems experienced by empon-empon farmers, namely the limited knowledge of the production techniques of empon-empon simplisia and the production facilities of empon-empon simplisia. These problems are experienced by partner "Gunung Jambe" SMEs, trawas sub-district, Mojokerto regency, East Java. To achieve the objectives of the PKM program, it is necessary to introduce science and technology regarding: (1) optimizing the manufacture of export quality simons (SNI: 01-3393-1994); (2) analysis of the nutritional content of simplicia empon-empon; (3) analysis of shelf life of empon-empon simplicia products. The implementation of PKM activities was carried out between May and September 2019. Based on the analysis of the nutritional content of the empon-empon simplicia product, it is known that the simplicia empon-empon contains $1.54 \%$ water; ash $9.45 \%$; carbohydrates $86.70 \%$; fat $0.91 \%$; and protein $1.41 \%$. From the results of the implementation of PKM in June 2019, there was very high enthusiasm from PKM participants. In addition, there were some inputs from the trainees related to the next activity which were conveyed through the trainee questionnaire.
\end{abstract}

Keywords: simplicia empon-empon, science and technologi introduction, PKM

\section{PENDAHULUAN}

Kabupaten Mojokerto merupakan salah satu kota di Jawa Timur yang memiliki lahan pertanian dan perkebunan yang luas dan subur. Salah satu pertanian yang berkembang sangat baik di kabupaten Mojokerto adalah pertanian empon-empon. Produk pertanian empon-empon dari petani di Kecamatan Trawas, Kabupaten Mojokerto dijual dalam bentuk segar di pasar-pasar tradisional di area Mojokerto dan sekitarnya. Selain itu sebagian produk pertanian empon- 
empon tersebut diolah menjadi bahan setengah jadi yaitu simplisia empon-empon, dan sebagian kecilnya diolah menjadi produk jamu atau obat herbal dalam bentuk serbuk.

Empon-empon merupakan produk pertanian yang saat ini banyak diminati masyarakat. Konsumsi empon-empon terus meningkat dari tahun ke tahun. Perubahan gaya hidup menjadi faktor utama meningkatnya konsumsi empon-empon. Perubahan gaya hidup ke arah pencegahan dibandingkan pengobatan juga menjadi faktor pendukungnya. Pilihan masyarakat saat ini adalah mencegah timbulnya penyakit, salah satunya dengan cara mengonsumsi jamu atau minuman herbal yang berfungsi untuk mencegah timbulnya penyakit. Berdasarkan fakta tersebut, saat ini telah menjamur produsen-produsen yang memproduksi jamu dan obat herbal.

Perlahan-lahan perputaran bisnis jamu di dalam negeri terus meningkat. Selama 4 (empat) tahun terakhir ini, omzet bisnis jamu mengalami peningkatan sebesar $50 \%$ dari Rp. 10 triliun pada tahun 2010 menjadi Rp. 15 triliun di tahun 2014. Namun demikian, berdasarkan data yang dimiliki Gabungan Pengusaha Jamu dan Obat Tradisional Indonesia (GP Jamu) pmzet bisnis jamu di dalam negeri masih sangat besar dan dapat mencapai Rp. 80 triliun/tahun (Wijayanto dkk., 2014).

Varian jamu terus berkembang dari waktu ke waktu sesuai dengan perubahan pasar. Pada zaman dahulu jamu identik dengan jamu rempah yang harus direbus, kemudian bergeser menjadi jamu bubuk, lalu berkembang menjadi jamu dalam bentuk cair (Prasetiyo, 2012). Bahkan beberapa produsen jamu dengan kemasan praktis seperti untuk obat masuk angin (Pribadi, 2009). Sayangnya potensi ini kurang digarap oleh pemerintah (Harmono dan Andoko, 2005). Salah satu hambatan yang banyak terjadi adalah terbatasnya fasilitas produksi. Kondisi tersebut telah menyebabkan rendahnya daya saing produk jamu tradisional dalam negeri di pasar internasional yang sangat memperhatikan kualitas produk, terutama yang terkait dengan higienitas produk (Rostiana dkk., 2007).

Sebagai negara agraris dengan produk hasil bumi meilmpah, khususnya emponempon, Indonesia memiliki potensi yang tinggi menjadi produsen jamu dan obat herbal. Namun demikian kuantitas yang tinggi tersebut belum diimbangi dengan tingginya kualitas produk bahan baku jamu.
Berlimpahnya produk empon-empon segar yang tidak diimbangi dengan kebutuhan pasar menjadi salah satu permaslaahan yang dihadapi oleh petani mepon-empon. Produk hasil panen empon-empon segar yang melimpah, namun tidak diimbangi dengan tingkat permintaan pasar seringkali merugikan petani karena produk emonempon segar yang tidak terjual atau terkonsumsi tersebut mebusuk dan terbnag sia-sia. Permasalahan ini memerlukan perhatian yang serius dan diperlukan solusi pemecahannya.

Menilik pada proses produksi jamu dan obat herbal, rangkaian proses pembuatan jamu herbal secara umum adalah dari pengolahan empon-empon segar menjadi simplisia, selanjutnya proses penghancuran (pembubukan) simplisia, pemasakan untuk memperoleh sari pati empon-empon (ekstrak), dan pengeringan untuk mendapatkan serbuk jamu dan obat herbal. Pengolahan empon-empon segar menjadi simplisia menjadi faktor penentu proses produksi jamu dan obat herbal dikarenakan simplisia merupakan bahan setengah jadi yang mempengaruhi kualitas jamu dan obat herbal sebagai produk jadi pada hilir produksi jamu dan obat herbal. Dilihat dari aspek ekonomi, harga simplisia empon-empon jauh lebih tinggi jika dibandingkan dengan harga empon-empon segar. Dengan demikian, menjual produk simplisia empon-empon lebih menguntungkan bagi petani daripada menjual produk empon-empon segar. Namun demikian, kualitas simplisia empon-empon tersebut harus memenuhi syarat mutu sebagai bahan baku jamu dan obat herbal.

Permasalahan keterbatasan pengetahuan mengenai teknik produksi simplisia emponempon, dan fasilitas produksi simplisia empon-empon yang kurang memadai menjadi permasalahan utama bagi petani empon-empon secara umum. Permasalahan tersebut dialami oleh UMKM mitra PKM Unesa, yakni UMKM Gunung Jamne, Trawas, pimpinan Yudha Presetyadi. UMKM Gunung Jambe memproduksi empon-empon segar, serta simplisia empon-empon, namun belum mengunakan standar yang memadai. Emponempon segar serta simplisia empon-empon yang diproduksi antara lain jahe, kencur dan kunyit.

Berdasarkan keterkaitan diantara keduanya, maka telah berhasil dilaksanakan program Pengabdian kepada Masyarakat "PKM-Penerapan Teknologi Produksi Simplisia Empon-Empon, Kelompok Tani 
Kecamatan Trawas, Kabupaten Mojokerto, Jawa Timur" yang dilaksanakan pada tahun 2019. Tjuan PKM ini adalah memeberdayakan petani empon-empon Kabupaten Mojokerto melalui upaya penerapan teknologi simplisa empon-empon dengan kualitas dan higienitas yang sesuai standar (SNI) sehingga dapat meningkatkan nilai jual produk. Manfaat dari program PKM ini adalah petani empon-empon di Kabupaten Mojokerto dapa umumnya, dan mitra PKM khususnya dapat melakukan ekspansi usaha pertanian empon-emponnya, dari produksi empon-empon segar menjadi produksi simplisia empon-empon yang emenuhi kualitas ekspor (SNI).

\section{METODE}

Metode yang digunakan dalam kegiatan PKM ini menggunakan beberapa metode sebagai berikut:

1. Sasaran kegiatan

Sasaran kegiatan PKM adalah anggota UMKM Gunung Jambe, Trawas, dan petani serta pengusaha empon-empon di seitar Kabupaten Trawas, Mojokerto

2. Tempat Kegiatan

Tempat kegiatan adalah di lokasi mitra UMKM Gunung Jambe, Kecamatan Trawas, Kabupaten Mojokerto

3. Prosedur Pelaksanaan

Kegiatan pelatihan ini terdiri dari beberapa tahap yaitu ;

a. Tim pengusul memberikan introduksi iptek dalam bentuk penyuluhan mengenai persyaratan mutu obat tradisional (jamu) (Peraturan Kepala Badan Pengawas Obat dan Makanan Republik Indonesia No. 12 tahun 2014), terutama yang terkait dengan produk jamu yang akan diproduksi dan dipasarkan bahan bakunya, agar dapat dihasilkan produk jamu dengan standar kualitas ekspor

b. Tim pengusul memberikan introduksi TTG mengenai produksi simplisia empon-empon, yakni teknik pembersihan, perajangan, dan pengeringan, agar dapat dihasilkan simplisia empon-empon dengan kualitas produk yang tinggi

c. Tim pengusul memberikan introduksi iptek mengenai kandungan gizi produk jamu, agar mitra dapat semakin meningkatkan eksplorasi pengetahuan seputar bahan baku jamu dan obat herbal dalam rangka mencapai kualitas produk simplisia yang dihasilkan

d. Tim pengusul memberikan pendampingan agar mitra kegaiatan dapat menjalankan kegaiatan PKM sesuai dengan yang diprogramkan, secara tuntas

\section{HASIL DAN PEMBAHASAN}

Pelaksanaan kegiatan PKM "PKMPenerapan Teknologi Produksi Simplisia Empon-Empon, Kelompok Tani Kecamatan Trawas, Kabupaten Mojokerto, Jawa Timur", kerjasama antara Tim PKM Unesa dan UMKM Gunung Jambe, Kecamatan Trawas, Kabupaten Mojokerto dilaksanakan bulan April hingga November 2019. Seluruh rangkaian kegiatan PKM yang dijalankan adalah sebagai berikut:

1. Survey persiapan mitra: 21 Maret 2019

2. Koordinasi dengan Disperindag Kab. Mojokerto: 3 April 2019

3. Koordinasi dengan perangkat desa mitra: 17 April 2019

4. Workshop I "Introduksi Iptek persyaratan mutu obat tradisional (Peraturan Kepala BPOM RI No. 12 Tahun 2014": 29 April 2019

5. Pelatihan I "Introduksi TTG teknik produksi simplisia, berupa teknik merajang dengan berbagai ketebalan": 14 Mei 2019

6. Pelatihan II "Introduksi TTG teknik produksi simplisia, berupa teknik mengeringkan, dengan beragai metode": 3 Juni 2019

7. Pelatihan III "Uji coba produksi menggunakan teknik merajang dan mengeringkan yang terbaik": 19 Juni 2019

8. Workshop II "Introduksi Iptek mengenai kandungan gizi produk jamu": 5 Juli 2019

9. Analisis kandungan gizi produk simplisia hasil uji coba produksi (uji laboratorium): 22 Juli 2019

10. Workshop III "Manajemen Bisnis dan Keungan": 7 Agustus 2019

11. Evaluasi teknik produksi dan hasil produksi: 23 Agustus 2019

12. Penyusunan laporan: 2 September 2019 - 30 September 2019

13. Publikasi: 2 Oktober 2019

14. Monitoring dan Evaluasi: 1 November 2019 
Kegiatan survey persiapan mitra dilakukan tanggal 21 Maret 2019. Survey ini bertujuan untuk memantau kondisi mitra, berikut kesiapan mitra dalam serangkaian kegiatan PKM. Dari hasil survey diketahui gambaran umum lokasi UMKM dan lahan pertanian empon-empon yang dikelola UMKM. Lahan pertanian empon-empon yang dikelola oleh mitra merupakan lahan pertanian seluas 250 $\mathrm{m}^{2}$ dengan kondisi lahan pertanian yang subur. Lahan pertanian empon-empon tersebut ditanami kencur, kunyit, dan jahe.

Kegiatan selanjutnya yakni koordinasi dengan Disperindang Kabupaten Mojokerto, serta koordinasi dengan perangkat Desa setempat. Kegiatan ini dilakukan tanggal 3 April 2019 dan 17 April 2019. Pada kegiatan ini, dilakukan koordinasi Tim PKM bersama Disperindag. Dimana diperoleh kesepakatan mengenai pendampingan terhadap mitra setelah kegiatan PKM berakhir oleh Disperindag Mojokerto. Hal ini sangat penting untuk dilakukan karena keberlanjutan pengembangan program PKM ini harus terpelihara.

Kegiatan keempat yakni, Workshop I, "Introduksi Iptek persyaratan mutu obat tradisional (Peraturan Kepala BPOM RI No. 12 Tahun 2014" yang dilakukan tanggal 29 April 2019. Dalam workshop ini dilakukan introduksi Iptek mengenai syarat mutu obatobatan tradisional yang dikeluarkan oleh BPOM. Introduksi ini perlu diberikan mengingat mitra yang memproduksi simplisia empon-empon sebagai bahan baku obat herbal. Dengan adanya introduksi ini, peserta workshop dapat membekali dirinya dengan pengetahuan seputar syarat obat tradisional, terkait mutunya. Dengan demikian produk simplisia empon-empon yang dihasilkan UMKM mitra dapat sesuai standart.

Kegiatan kelima, yakni Pelatihan I "Introduksi TTG teknik produksi simplisia, berupa teknik merajang dengan berbagai ketebalan" yang diadakan tanggal $14 \mathrm{Mei}$ 2019 di Laboratorium Biokimia FMIPA Unesa. Dalam pelatihan ini, Bapak Yudha selaku ketua UMKM Gunung Jambe mendapatkan pelatihan mengenai teknik merajang simplisia dalam berbagai ketebalan. Diharapkan setelah mendapatkan pelatihan ini, bapak Yudha beserta tim memiliki skill yang lebih di bidang tersebut.

Kegiatan keenam, yakni Pelatihan II "Introduksi TTG teknik produksi simplisia, berupa teknik mengeringkan, dengan beragai metode" pada 3 Juni 2019. Dalam pelatihan ini, Bapak Yudha selaku ketua UMKM
Gunung Jambe mendapatkan pelatihan mengenai teknik mengeringkan simplisia dalam berbagai metode. Diharapkan setelah mendapatkan pelatihan ini, bapak Yudha beserta tim memiliki skill yang lebih di bidang tersebut. Dari hasil pelatihan ini diketahui bahwa teknik pengeringan kombinasi. Yakni pengeringan menggunakan sinar matahari yang dikombinasi dengan pengeringan menggunakan oven adalah cara yang terbaik untuk mengeringkan simplisia.

Kegiatan ke tujuh, yakni Pelatihan III "Uji coba produksi menggunakan teknik merajang dan mengeringkan yang terbaik" pada 19 Juni 2019. Pada kegiatan ini dilakukan praktik atau uji coba terhadap hasil pelatihan pertama dan kedua. Dari uji coba ini nampak peningkatan iptek dari mitra.

Kegiatan ke delapan, yakni Workshop II "Introduksi Iptek mengenai kandungan gizi produk jamu" pada tanggal 5 Juli 2019. Workshop ini berisi paparan mengenai kandungan gizi yang dimiliki bahan baku jamu dan produk jamu. Melalui workshop ini, diharapkan UMKM mitra dan masyarakat sekitar lokasi PKM yang menjadi peserta workshop meningkat pengetahuannya mengenai kandungan gizi bahan baku jamu dan jamu herbal. Dengan peningkatan pengetahuan ini maka mitra dan peserta workshop yang lain dapat menigkatkan kualias produk mereka.

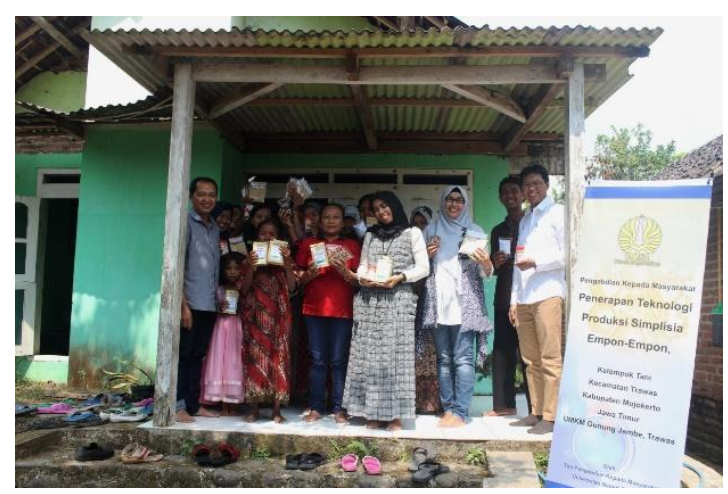

Gambar 1. Workshop II "Introduksi Iptek kandungan gizi produk jamu"

Kegiatan ke sembilan adalah analisis kandungan gizi produk simplisia hasil uji coba produksi (uji laboratorium) pada tanggal 22 Juli 2019. Dari hasil analisis ini diketahui kandungan gizi produk simplisia produksi mitra, yakni kadar air sebesar $1,54 \%$, kadar abu sebesar 9,45\%, karbohidrat sebesar $86,70 \%$, lemak sebesar $0,91 \%$ dan protein sebesar $1,41 \%$. 
Kegiatan ke sepuluh, yakni Workshop III "Manajemen Bisnis dan Keungan" pada tanggal 7 Agustus 2019. Pada kegiatan ini mitra dan peserta lain diberikan introduksi mengenai menejemen bisnis dan keuangan yang berguna bagi pengelolaan usaha mereka.

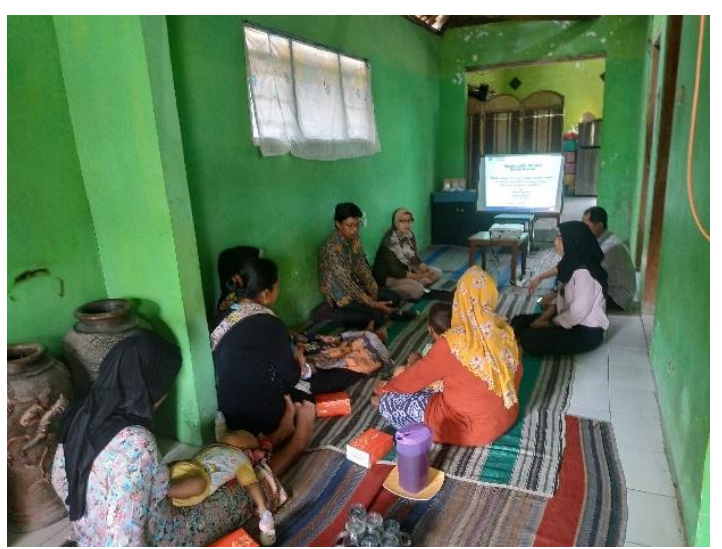

Gambar 2. Workshop III "Manajemen Bisnis dan Keungan"

Kegiatan ke sebelas, yakni "Evaluasi teknik produksi dan hasil produksi", pada tanggal 23 Agustus 2019. Pada kegiatan ini, tim PKM Unesa memberikan evaluasi teknik produksi serta hasil produksi UMKM mitra. Pada tahap ini dilakukan identifikasi mengenai hasil produksi UMKM mitra.

Dari serangkain kegiatan PKM yang dilakukan dan berdasarkan angket PKM yang telah diisi oleh peserta PKM, maka nampak antusiasme yang sangat besar dari mitra dan peserta PKM yang lain.

Dari isian angket, sebagian besar peserta menginginkan ada keberlanjutan program, dan kegiatan serupa di waktu yang akan datang.

\section{SIMPULAN DAN SARAN}

Berdasarkan hasil kegiatan PKM bersama UMKM Gunung Jambe, Trawas, Mojokerto dan warga sekitar dapat disimpulkan bahwa "PKM-Penerapan Teknologi Produksi Simplisia Empon-Empon, Kelompok Tani Kecamatan Trawas, Kabupaten Mojokerto, Jawa Timur" serangkaian kegiatan berjalan lancar dan antusiasme peserta sangat besar. Hampir seluruh peserta menginginkan adanya keberlanjutan kegiatan, serta kegiatan lain yang serupa, yang dapat meningkatkan kemampuan mereka. Antusiasme ini ditandai nampak pada sesi tanya jawab serta jawaban angket yang diberikan yaitu sebanyak $100 \%$ peserta tertarik dengan materi pelatihan, sebanyak $88 \%$ peserta menyatakan bahwa materi pelatihan merupakan pengetahuan baru.

\section{Saran}

Saran dari kegiatan pelatihan ini adalah mitra diharapkan dapat mengoptimalkan produksi mereka sehingga dapat meningkatkan pendapatan mereka.

\section{DAFTAR PUSTAKA}

Harmono, Andoko, A. 2005. Budidaya dan Peluang Bisnis Jahe. Jakarta: Penerbit Agromedia Pustaka.

Prasetiyo, Y. T. 2012. Instan : Jahe, Kunyit, Kencur, Temulawak. Kanisius, Yogyakara.

Pribadi, E. R. 2009. Pasokan dan Permintaan Tanaman Obat Indonesia serta Arah Penelitian dan Pengembangannya. Perspektif Review Penelitian Tanaman Industri, vol. 8, no.1

Rostiana, O., Soleh, D. 2007. Teknologi Unggulan Kencur. Pusat Penelitian dan Pengembangan Perkebunan, Bogor.

Wiyanto, G., Ma'ruf, A., Savitri, E. 2014. Panen Rupiah dari Ladang Jahe. Bhafana Publishing, Jakarta. 